\title{
Electronic Commerce and the information highway
}

Citation for published version (APA):

Soete, L. L. G. (2001). Electronic Commerce and the information highway. In L-A. Lefebvre, E. Lefebvre, \& P. Mohnen (Eds.), Doing Business in the Knowledge-based Economy, . Facts and Policy Challenges (pp. 307-327). Kluwer Academic Publishers. https://doi.org/10.1007/978-1-4615-1587-6_10

Document status and date:

Published: 01/01/2001

DOI:

10.1007/978-1-4615-1587-6_10

Document Version:

Publisher's PDF, also known as Version of record

\section{Please check the document version of this publication:}

- A submitted manuscript is the version of the article upon submission and before peer-review. There can be important differences between the submitted version and the official published version of record.

People interested in the research are advised to contact the author for the final version of the publication, or visit the DOI to the publisher's website.

- The final author version and the galley proof are versions of the publication after peer review.

- The final published version features the final layout of the paper including the volume, issue and page numbers.

Link to publication

\footnotetext{
General rights rights.

- You may freely distribute the URL identifying the publication in the public portal. please follow below link for the End User Agreement:

www.umlib.nl/taverne-license

Take down policy

If you believe that this document breaches copyright please contact us at:

repository@maastrichtuniversity.nl

providing details and we will investigate your claim.
}

Copyright and moral rights for the publications made accessible in the public portal are retained by the authors and/or other copyright owners and it is a condition of accessing publications that users recognise and abide by the legal requirements associated with these

- Users may download and print one copy of any publication from the public portal for the purpose of private study or research.

- You may not further distribute the material or use it for any profit-making activity or commercial gain

If the publication is distributed under the terms of Article $25 \mathrm{fa}$ of the Dutch Copyright Act, indicated by the "Taverne" license above, 


\section{ELECTRONIC COMMERCE AND THE INFORMATION HIGHWAY}

Luc Soete

Untiversity of Maastricht \& MERIT

\section{INTRODUCTION}

What probably strikes most readers of recent policy documents discussing the subject of electronic commerce and the information highway is the extent of the expectations business people and policy-makers have with respect to the expected growth impact of such new forms of electronic, interactive, digital commerce, particularly when compared to the current, limited, occurrence of the phenomenon. There is probably no area where, considering the relatively limited technological improvements still required, the gap between the current phenomenon and expected future use is as large as in the case of electronic commerce. For instance, Figure 1 illustrates the Internet growth forecast in Europe for the period 1998-2001 in terms of on-line population and Internet revenues. While the growth in penetration rate is substantial, a threefold increase over the next three years, the forecast growth in revenues is staggering: from just over $\$ 1$ billion in 1998 to $\$ 64$ billion in 2001. By comparison, U.S. revenues are estimated at more than $\$ 200$ billion in 2001 . 

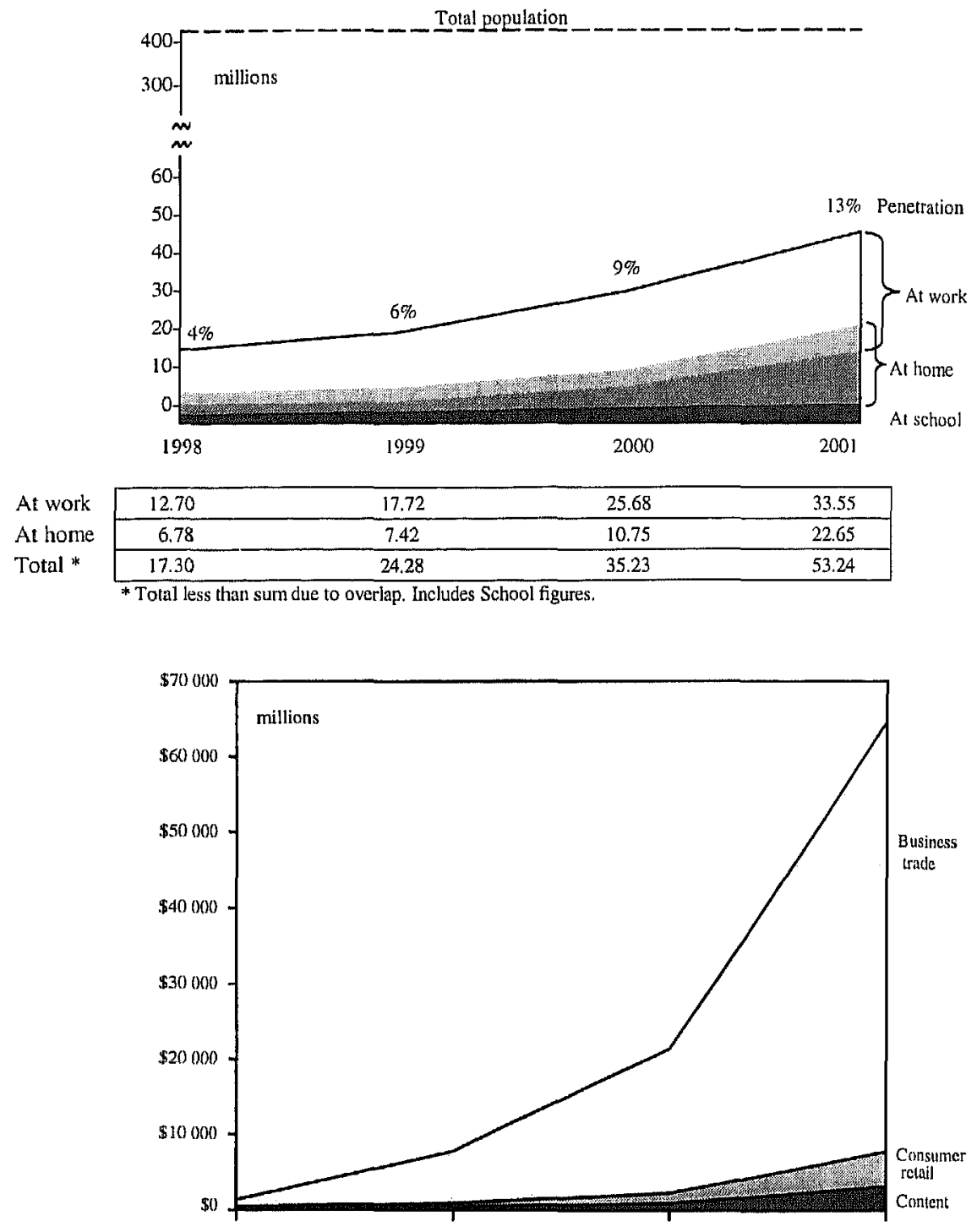

Business trade

Consumer retail

Content

Total

\begin{tabular}{|cccc|}
\hline 1998 & 1999 & 2000 & 2001 \\
\hline$\$ 879$ & $\$ 7,208$ & $\$ 19,285$ & $\$ 56,713$ \\
\hline$\$ 165$ & $\$ 372$ & $\$ 1,296$ & $\$ 4,568$ \\
\hline$\$ 124$ & $\$ 335$ & $\$ 966$ & $\$ 3,081$ \\
\hline$\$ 1,168$ & $\$ 7,915$ & $\$ 21,547$ & $\$ 64,362$ \\
\hline
\end{tabular}

(Source! Forrester Research, Inc.)

Figure 1: The European on-line population and growth of Europe's Internet revenues 
Such dramatic forecasts lead one almost automatically to the presumption that there must be particularly strong impediments of various sorts preventing the rapid diffusion of electronic commerce so far. These barriers or impediments can be of a technical (e.g., encryption), legal (regulations), economic (costs) or simply user-friendly nature (access through PC or TV and mobile phone). The essential assumption from the policy perspective is that governments can help private industry in overcoming many of these barriers. Furthermore, overcoming those barriers is likely to involve finding international solutions, since the real growth potential of electronic commerce involves, in the first instance, "global" access by firms and individuals to suppliers of goods and services of all kinds. Hence, and not surprisingly, this has been to some extent the bread and butter of most recent policy reports on the subject, whether from national authorities (including the Canadian report "Electronic Commerce in Canada - Priorities for Action", 1997/8; the U.S. policy notes on "A Framework for Global Electronic Commerce", July 1997; the Japanese policy statement in "Towards the Age of the Digital Economy", May 1997; and the European Union's "European Initiative in Electronic Commerce", April 1997) or international organizations (see, among other things, the many contributions from the OECD in particular but also the WTO and WIPO).

In this paper, I will not discuss these relatively common policy issues. They are relatively well known by now and evolve rather quickly because of new technical solutions. There is an obvious tendency to reduce the debate to such technical issues: to finding appropriate technology-push solutions to the many security, privacy or consumer protection problems. In so doing, the basic premise is, generally speaking, that the current legal framework regulating "meatspace," as some authors are now calling real, physical commerce, can be adapted to "cyberspace." While this will certainly be the case for a number of products and consumers, whether business or individuals - a good example is given in Box 1 with respect to the licensing of downloaded music - there will also be many cases where such technical solutions will not really provide the conditions of trust and transparency typical of physical, human interactions. From this perspective, not to open the "black box" of the more human cultural and social barriers, considering, for instance, the role of shopping as a social activity, seems to ignore some of the most essential features of "commerce" activities. 
Box I: From http://www.MusicTrial.com

The first integrated solution for licensing music in the digital age will be formally tested this autumn by U.K. music rights societies MCPS and PRS and the leading U.S.-based developer of secure on-line music delivery systems, Liquid Audio.

Anyone visiting the $w w w . M u s i c T r i a l . c o m$ Web site will be able to download CD-quality music for free using the Liquid Audio MusicPlayer (which can also be downloaded free from www.LiquidAudio.com). The music tracks available for download have been provided free of charge by PRS and MCPS members for the duration of the 90-day trial.

Utilizing the Liquid Audio music distribution system, the trial partners will track music downloads and users will be given automatic copyright clearance in accordance with the licence granted to the owner of the sound recording by the copyright holder of the musical work. The prototype integrated licensing system developed by MCPS and PRS for MusicTrial.com provides a template for future audio distribution and licensing management on the Internet and represents a critical step forward for on-line music sales. MusicTrial.com demonstrates how music can be acquired and licensed for use in one simple on-line transaction.

This unprecedented trial represents the first significant step towards finding a global solution for the legal trading of copyright music and sound recordings in the electronic age.

More information fromacrookes@prs.co.uk

To avoid this critique, the assumption is often made, as in Figure 1, that it is the business-to-business segment of electronic commerce that will take the lead, where such barriers are unlikely to play a significant role. For the next five years, most forecasts expect the business-to-business segment to be the driving force behind the expected rapid growth of e-commerce. This will allow for lower costs through international access to cheaper and more efficient suppliers, further opening up and enlarging market opportunities, particularly with respect to small and medium-sized firms, and through better use of available capital. In short, it will change the business fundamentals of exchange both internally and externally with suppliers and customers. From this perspective, it is likely that e-commerce represents to some extent a flood of new market opportunities. However, in making these at first sight rather reasonable assumptions, one seems to underestimate the relatively broad extent of electronic interchange that already exists between various supply chains from raw materials production down to retail sale businesses in highly developed economies such as the U.S., Canada, Japan or Europe. From this point of view, electronic commerce appears more like an evolutionary transformation, a further, undoubtedly more ubiquitous, efficiency-improving factor in a long series of improvements in logistics and wholesale and retail 
trade activities, from bar coding to EDI to e-commerce. As a consequence, and maybe somewhat paradoxically in terms of expectations of the huge growth and efficiency-enhancing effects of e-commerce, these improvements appear to be more of the incremental type. They will be small in sectors where large, sophisticated multinational companies already operate, as in the food or automobile sectors, in a logistically sophisticated way, but probably large in sectors with many SMEs and a more overt domestic focus.

In saying this, it will be clear that the definition of the relevant concept of ecommerce used here interacts with the information highways, i.e., the conduct of commerce activities - buying, selling and transactions of all kinds - over the new information highway, i.e., the Internet. To argue that e-commerce is not new and includes all commerce transactions involving some use of information and communication technologies, such as ordering by telephone, fax, or Minitel, or payment by credit or debit cards, would effectively mean that practically all commerce is now e-commerce. Within the European context of the existence of systems such as Minitel, such a definition does not provide sufficient insight into the new policy challenges posed by the new forms of ecommerce.

In the case of business-to-consumer commerce, the long-term growth impact of e-commerce is likely to be even more significant given the greater opportunities for substitution of physical commerce for electronic commerce, ${ }^{\text {ii }}$ the possibilities for greater market transparency allowing consumers to identify products at the lowest price, and the new opportunities for suppliers to "version" goods (Varian, 1997) more directly to consumers' needs. The balance between these consumer economic advantages versus possible social and cultural needs for shopping is likely to differ across product categories. Hence the diffusion path of such new forms of electronic commerce is likely to be very differentiated, with some goods, such as software, computer games and other content programs, $\mathrm{CDs}$, and books rapidly being traded on-line on the Internet (see Table 1), while many others continue to rely on physical commerce. Although the likely growth in such electronically traded product categories may well be very high, the overall growth impact again does not really fit the overall growth expectations of electronic commerce. 
Table 1: On-line purchases for various categories of goods

\begin{tabular}{lc}
\hline \multicolumn{1}{c}{ Category } & $\%$ of users who have purchased \\
\hline Software & $16.0 \%$ \\
Books & $14.0 \%$ \\
Computer Hardware & $13.0 \%$ \\
Music & $11.0 \%$ \\
Home Electronics & $6.5 \%$ \\
Videos & $5.0 \%$ \\
Travel Services & $5.0 \%$ \\
Tickets for Events & $4.0 \%$ \\
Casual Clothes & $3.0 \%$ \\
Other Clothes & $1.5 \%$ \\
\hline
\end{tabular}

The line taken in this paper is that the policy discussion on electronic commerce has been overly dominated, as is often the case, by the search for technological and legal solutions to cyberspace issues, assuming rather quickly that physical and electronic commerce are perfect substitutes for each other. In doing so, one is not only likely to overestimate the substitution possibilities of physical commerce and electronic commerce, one is also likely to underestimate the new growth possibilities of electronic commerce outside of traditional commerce fields. It is in this sense that the word "e-com" seems particularly badly chosen and very reminiscent of previous technological transformations such as "the wireless", which were expected merely to substitute for now old, nearly abandoned human activities. More than in these earlier, primarily technologically driven cases, the discussion of electronic commerce will have to acknowledge to a much greater extent the particular features and relative merits of physical versus electronic communication and exchange including money exchange. This discussion will also have to address the more fundamental question, as a number of economists dealing with information economics have been doing for some time now, of whether the various technological and legal attempts to create such familiar market relationships will entail the same market optimality and social welfare outcomes. We turn to this issue in the next section.

However, as we will discuss in the third section of the paper, limiting the debate on e-commerce to the distribution of goods and services would seem to miss the essence of what the information highway is all about. From this perspective, the real growth of electronic commerce does not seem to lie in the simple substitution of physical commerce and electronic commerce. Rather, it 
seems to reside in what we will call "e-exchange," i.e., the opportunities offered by electronic networks for new forms of exchange and communication, across businesses, between businesses and consumers, and between consumers. The main "commerce" challenge is to generate value out of such new forms of exchange. From the perspective of Europe's relative lagging position in ecommerce, two areas appear to be of special relevance: e-banking, which in the European context of Euroland might become the leading sector, establishing new conditions of security, trust, even tax compliance, and public services. In the latter case, it might be argued that, in the European context of large public sectors, e-exchange may become an enabling factor for broad public access to information highways, as discussed in section 4.

If these challenges are not addressed, the new opportunities of the information highways are likely to become part of the underground economy. They may become part of that contribution to overall well-being that economists have little grip on, since it is not measured, not paid for, and only contributes in a virtual sense to economic growth, national income, or tax revenues. We will conclude this paper by arguing that, while unfortunate, this trend may actually force economics to readdress some of the old well-being and "happiness" issues. These issues were eliminated long ago, when microeconomics turned utilitarian, but are probably of growing importance in a society in which the immaterial satisfaction of easy information and communication becomes an intrinsic part of well-being and happiness.

\section{ON THE NATURE OF ELECTRONIC EXCHANGE MARKETS}

There is little doubt that one of the main achievements of economics has been the pervasive illustration that prices in well-functioning markets lead both in a static and in a dynamic sense to "optimal" outcomes. In a static sense, "free-market" prices solve the distribution of scarce commodities among consumers better than any other system - anyone not willing to pay the market price will simply not be allowed to consume the commodity. In a dynamic sense, prices also signal profit opportunities to potential suppliers, and their entry and competition with the incumbent brings prices into line with production costs. Under the well-known assumptions of free, well-functioning, open markets, this market price system will create the maximum amount of social surplus. It could be argued from this perspective that the failure of the 
plan-based socialist system was, in the first instance, a failure to cope with these dynamic challenges. It failed to increase social surplus, at the precise moment (the 1970s and 1980s) when changes in new production methods and new product opportunities were also challenging the capitalist market system.

However, for markets to function well, three essential structural conditions need to exist: excludability, rivalry and transparency. These conditions are to some extent intrinsic to the exchange of material goods.

Thus, the exchange between seller and buyer needs to involve the exclusive exchange of ownership over the particular product. Once traded, the product is no longer the property of the seller but the exclusive property of the buyer. It is this feature which is, of course, behind the notion of economic scarcity and provides the impulse for new output activities on the part of the seller. Another feature typical of material production and open markets is the notion of rivalry. While significant economies of scale are likely to exist in the production of most material goods, the selling of a single good will still imply that the same good cannot be sold to another buyer. At the same time, while there might be significant entry barriers, the threat of new entry will imply that suppliers will not be in a position to keep prices substantially higher than costs. Rivalry is, in other words, a major and essential condition for markets to generate optimal outcomes. Finally, the exchange of material goods involves a high degree of transparency: the buyer can see, feel, test, smell, in some cases even taste the product on offer.

In the case of the exchange of a purely informational "electronic" good, it can be argued that none of these conditions hold. The owner of the digital commodity selling his product in the marketplace will have difficulty preventing buyers, or anyone else for that matter, from copying and reselling it. Excludability will typically be difficult if not impossible to achieve. Rather than a purchase and sale relationship, the exchange will look more like a gift. The creation and enforcement of excludability is thus an absolute and first condition for such markets to exist. Hence, encryption, watermarks and various other forms of tracing and monitoring property rights are a central focus of most policy documents on e-commerce. Without these rules creating excludability, no optimal level of production can be achieved and little indication can be obtained of the sort of products that are wanted by potential buyers.

Yet the creation and strengthening of such property rules has immediate implications, of course, for the openness and degree of competition in such markets. If property protection is absolute, whereas at the same time marginal production costs are minimal, possibly even nil as is typical for many digital 
goods, many potential users will not consume and, compared to the social optimum, too little will be produced (as in the case of the virtual monopolist). At the same time, the individual producer is now being guaranteed a fixed property income and has little to fear either from competitors and or from consumers, who can only choose to buy the particular product from him. This non-rivalry characteristic directly challenges the optimal market outcome. It raises a very large set of welfare questions characteristic of what has been called network economics and involving competition policy, regulation - for instance, price control in the case of a natural monopoly - standards and interconnectivity, etc.

Finally, despite the tremendous opening-up of trading possibilities and the increase in market transparency, the actual exchange of a digital commodity will involve, almost by definition, a high degree of information asymmetry between seller and buyer. Many of the new forms of markets emerging on the Internet are typical illustrations of such problems of information asymmetry and well known in information economics. New intermediaries emerge to assist buyers in their search; alternatively, goods may be offered for free, paid for by advertising or by subsequent upgrades; a limited preview of the good may be offered for free; etc. We will return to some of these new forms of markets and intermediaries in the following section. Yet, it is clear that the traditional physical marketplace is being replaced by a far more complex and diversified set of exchange methods in which the value of what the content seller is offering is likely to differ greatly among individual consumers - hence the crucial importance of so-called versioning (Varian, 1997) - and is distributed among many intermediaries that bring the buyer into contact with the supplier - with significant shifts in the value chain as highlighted in socalled attention or click economics.

On all three accounts, it is difficult to simply subscribe to the notion that the newly created markets will, as in the exchange of physical goods, guarantee optimality, As de Long and Froomkin (1998) put it forcefully: "What used to be second-order 'externality' corrections to the invisible hand have become first-order phenomena" in the cyberspace world. Nowhere is this more clearly illustrated than in the artificial creation of excludability. In contrast to the old notion of the invisible hand of the market, excludability is human-made. Its length, its height, its breadth, as in the case of patent protection, are likely to have major implications for market structure, competition and, more generally, welfare. Furthermore, while national rules might be enforced and hence domestic excludability could succeed in generating an optimal outcome, 
international differences in the protection of property rights might undermine such domestic attempts at strengthening intellectual property. In other words, the human-made rules of excludability involve, practically by definition, particular sectoral and/or national lobbies. ${ }^{\text {iii }}$ Excludability also questions the traditional arguments about the welfare gains from trade: for example, strengthening the imposition of the international property regime worldwide might well shift the terms of trade in favour of countries specializing in digital goods and content to the disadvantage of countries that specialized more in manufactured commodities. ${ }^{i v}$ As argued elsewhere, this might well be one of the underlying "real" factors behind the Asian crisis.

The variety of new forms of markets and exchange on the Internet also illustrates that it is very difficult to draw a distinction between electronic "commerce" and electronic exchange, whereby the former would be limited to purely commercial transactions. As different forms of information markets emerge, it will be clear that many different forms of electronic exchange will have an (in)direct impact on consumer satisfaction and costs. ${ }^{v}$ The electronic commerce debate therefore needs to be broadened to include all forms of electronic exchange. In so doing, we would highlight the fact that the emerging information society is much broader than an electronic commerce economy and that the policy challenges are also much more pervasive. Before entering into this discussion, we shall focus on some of the more narrow "commerce" issues.

\section{FROM E-COMMERCE TO E-EXCHANGE VALUE}

For the commercial exchange of goods to take place, there are a number of prerequisites well known in economic theory. Specialized infrastructures for the organization of commercial transactions are obviously needed, as they have been since the Middle Ages, such as marketplaces or trade fairs, particular trade sub-areas in towns (one may think of Shinjuku in Tokyo with respect to electronics), and more recently malls of various sorts in suburbs. As argued by Chandler and others, the organization of commerce from wholesale distribution, through various intermediaries such as representative agents and importers, down to retail shops has aimed at reducing the associated investment costs so as to better adjust to the sometimes erratic movements of final demand. Such infrastructure costs will, however, only be recuperated if commerce actually takes place. Another essential cost feature associated with commercial transactions is, of course, the information search cost preceding a 
possible transaction. In transaction theory, these are called the ex ante transaction costs.

On both accounts, information highways are likely to significantly reduce costs. The emergence of virtual malls is likely to replace the physical infrastructure; similarly, the information search costs are likely to become significantly reduced due to the ease of electronic access and the available databases on products and suppliers. Transaction costs are thus likely to fall and existing intermediary costs to decline. This argument appears to be valid for both intermediary and final demand.

Alongside these immediate short-term impacts, there are of course longerterm impacts that are more associated with new possibilities for trade and commercial exchange. Electronic exchange is likely to lead to a substantial reorganization of markets with the value chain shifting across businesses. The phenomenon of outsourcing is typical of such a reorganization. As witnessed in the rapid growth of business services, activities that are not part of the core manufacturing or service production of a firm can now be carried out more efficiently outside of the firm, by specialized companies. Similarly, with respect to final demand, goods and services can become more versioned to the particular needs of the consumer. In the extreme case, "untradable" services "untradable" because of the physical presence of the service delivery - can now be effectively traded, dramatically raising the tradable value of such services.

Table 2 classifies these impacts for both intermediary and final demand: short-term cost impacts associated with the reduction in transaction costs and the disappearance of intermediaries (disintermediation) and long-term growth impacts associated with the reorganization of production and markets and new commercial transactions.

Table 2: Impacts for both intermediary and final demand

\begin{tabular}{|l|ll|}
\hline & \multicolumn{1}{|c|}{ Short-term } & \multicolumn{1}{c|}{ Long-term } \\
\hline Intermediary & Division of labour & Organization of markets \\
Final & Disintermediation & Reintermediation \\
\hline
\end{tabular}

Most of the high expected growth impact of electronic commerce is associated with this typical dual feature of technological advance: a significant cost-reduction impact, increasing efficiency and freeing up resources, and a more direct growth-enhancing impact associated with new growth opportunities. 
The doubts raised with respect to the actual growth likely to occur are twofold.

First, the discussion of electronic commerce, particularly in the business-tobusiness segment, seems to ignore the existence of various quite common forms of electronic exchange between businesses such as electronic data interchange (EDI) or bar-coding systems. These systems, which are in operation in many sectors (the food sector being probably the most developed one), have existed for over 15 years and have to some extent formed the basis for the trend towards outsourcing. While these kinds of EDI can be viewed as early forms of electronic commerce, their widespread use across businesses leads one to question somewhat the immediate, additional growth impact of further reductions in transaction costs associated with the emergence of information highways, at least in the business-to-business segment.

Of course, in many countries EDI systems have remained limited in use to only a couple of sectors; many of the networks used have remained very costly because of their proprietary nature and their compatibility is often limited. It is most likely that the open standard, compatibility and low costs associated with information highways such as the Internet will significantly expand the possibilities for more extensive and widespread use of EDI across sectors. Particularly with respect to small and medium-sized firms and new access possibilities for international customers and suppliers, a significant new impulse can be expected. At the same time, it is important not to underestimate the widespread nature and integration of use of EDI and bar coding in many sectors. The bar-coding system, for example, has been continuously upgraded, allowing systematic integration of inventory data, payment systems, and even sales or value-added tax reporting. The security and reliability of the system is well accepted in many sectors and often contrasts sharply with the, at least perceived, insecurity of information highways and the new forms of electronic commerce. Similarly, most business transactions are already the subject of various forms of electronic final transfer. The guaranteed security and trust in such systems is likely to be an important factor in slowing down the use of other more open, Internet-based solutions.

In other words, many of the impacts described above with respect to reduction of transaction costs as a result of electronic commerce in intermediary demand have already occurred. While further growth is likely, there is a tendency to overestimate the additional growth impact.

Second, and with respect to final demand, the reduction in transaction and intermediary costs is undoubtedly also being accompanied by new information search costs. The dramatic growth in access to information has also led to 
information overload, to new search costs. In other words, the reduction in intermediary and transaction costs is likely to be accompanied by the emergence of new intermediaries to select relevant information. The emergence of these new intermediaries, so-called intelligent agents, while likely to solve some of the new search costs for final consumers, will also raise transaction costs. Furthermore, to the extent that such agents also take away some of the more "desirable" search activities of consumers, they are likely to be confronted with social and cultural barriers. For some products and services, commerce will remain in the first instance a social activity, where personal contact, search, and experimentation continue to be an essential feature. As the limited success of mail-order selling, at least in Europe, has illustrated, for many products the pleasure of acquiring something will remain an activity people like to be directly involved in themselves, whereby personal contact remains an essential feature. In other words, electronic commerce continues to be constrained by human beings' desire to be personally and directly involved in consumption.

Yet there is little doubt that the emergence of information highways and the Internet has led to an explosion of new activities involving the search for information: data, facts, news items in all forms, available at one's fingertips and stored in millions of books, articles, databases, libraries, websites, etc. Such new possibilities for data-mining more and more information are leading to better informed judgements not just in commercial buying and selling but in all kind of activities. Some of these are essential for one's work, others are purely of the hobby type, and still others simply contribute to one's personal general knowledge, interest in democratic control and so on. On the other hand, the emergence of information highways and the Internet has led to new opportunities for communication - not just for business or private family communication as in one-to-one "commercial" telephone conversations, but in all kinds of one-to-many communications such as virtual video conferences, debating clubs, chat rooms, and so on, identifying people elsewhere on the globe with similar work, leisure, hobby, personal and political convictions. Such forms of exchange do not appear to have any more commercial "value" than is being paid for in terms of Internet access charge and telephone costs. Nevertheless, it is obvious that such electronic communication activities represent a large part of the increased welfare associated with information highways and that they indirectly contribute to economic performance and feelings of well-being. 
This explains why, in the current debate on the information society, limiting the discussion to e-commerce - the commercial exchange or the selling and buying of goods and services - appears too minimalist. It reduces the relevant growth and welfare parameters to only economically directly measurable concepts such as lower costs and larger markets.

\section{GENERATING E-EXCHANGE VALUE OUT OF PUBLIC SERVICES}

There are two areas of economic activity which in essence involve only the handling of information and thus appear from the outset to be crucial "enabling" areas for the more narrowly defined e-commerce to take off: financial services and public services.

Financial services have a long history with the use of information and communication technologies. In the 1960s, they were at the forefront of a rapid process of automation, quickly becoming one of the main customers of the large mainframe computer sector. Similarly, with the advent of the minicomputer followed by the PC, the financial sector was quick to pick up these new technologies, rapidly adjusting its organizational structure to the new, more decentralized opportunities offered by the personal computer. As opposed to this more process-driven use of information and communication technologies, the advent of the ATM has allowed banks also to respond more directly to consumer needs for easier, 24-hour access to money. Under pressure from their large customers, concerned by security issues, banks have also become instrumental in the immaterial exchange of money between businesses, salary and wage payments and, increasingly, final consumer payments (PIN codes, credit cards and electronic debit cards).

With respect to electronic banking, most banks now offer home banking services to their clients, who can log in from their computer through a modem onto the bank's computer using a specific protocol. Such forms of PC banking can best be compared with EDI, in light of our discussion above. While there is a digital electronic interchange, it is a closed system. One cannot transfer savings from one bank to another bank offering better rates. Internet banking involving open access and use of the Internet is still relatively limited, with the exception probably being Finland and Sweden, and more focused on financial services of all sorts, each searching for the elusive market niche. 
By itself, as Figure 2 illustrates, there is little doubt that there are substantial cost advantages to banks in shifting from physical interchange to electronic interchange. But, as Figure 2 also illustrates and in line with some of the arguments set out in the previous section with respect to the incremental nature of e-commerce as opposed to EDI and bar coding, the cost advantage of the final step from PC banking to Internet banking is relatively small. As in the case of e-commerce, the real benefit of Internet banking will, in the first instance, be linked to increased competition and consumer satisfaction. Traditionally, these features are not what existing banks are particularly interested in. Even today, Internet banking and, more generally, Internet-based financial service provision has been the domain of small players, as in Finland, or newcomers.

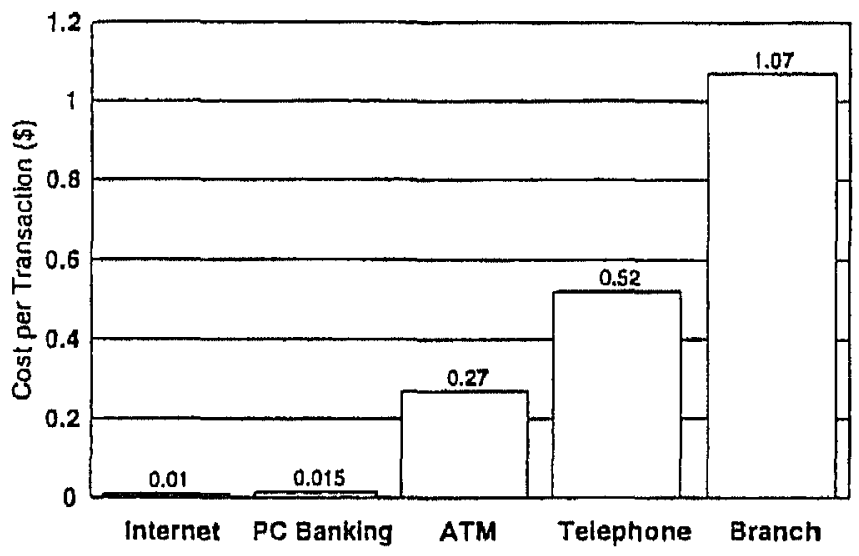

Figure 2: Intemet banking is cheaper for banks (Source: Booz-Allen \& Hamilton)

This is why the combination of the introduction of the Euro, with its major impact on financial restructuring and competition in the banking sector, and Internet banking looks so promising in the European context. The shift in trust, habits, and national identity which is being brought about by the replacement of a national currency with the new, unknown Euro is in many ways rather similar to the shift in trust and habits required to move to purely on-line Internet banking and other financial transactions. At the same time, the transparency brought about by prices, wages, and rates being denominated in a common currency across the 15 member states is likely to provide a major impetus to European commerce and exchange, and the Internet will probably be the tool to realize and bring about such transparency and growth. With the structural changes occurring in the banking sector, Internet banking, as an area where such 
on-line exchange can become complete, is likely to become the major growth area for such electronic commerce and exchange. At present, many of the existing Internet banking services are typically limited to national or domestic clients. In foreign countries, a bank will typically operate through its physical retail banking presence. The combined effect of the Euro and information highways makes such electronic pan-European services attractive to both existing and new banks, opening up their national markets and enabling clients to access their bank wherever they are in Europe. ${ }^{\mathrm{vi}}$

A second area that might become a "pulling" factor for Internet uptake and ecommerce is public services.

Certainly within countries such as Canada and many EU countries, which have a large and diversified public sector, one may view public services in their broadest sense, i.e., including health, education, transport, government services, and public utilities, as the most promising area of electronic commercial and exchange value creation.

First of all, the simple fact of the matter is that public administration, whether at a national or local level, is first and foremost an information service, often involving many private and public information features. This raises not only the problems of excludability and rivalry typical of commercial markets but also important questions about privacy, access and democratic control, of direct relevance to many of the new forms of e-commerce and e-exchange.

Second, because the physical and human capital investments in such activities are often substantial, such publicly sponsored and initiated investments provide plenty of opportunities for improved connectivity, standard setting, etc. Public administration might, in many instances, take the lead, given the high risks involved in investing in new, interactive information systems, and open up new market opportunities for private partnerships in the development, execution and maintenance of new information systems.

Third, the public administration sector is probably the ideal one for internal organization experiments, bringing to the forefront the many organizational bottlenecks in public bureaucracies, and enabling diversity at the local administration level. Such experiments and pilot projects, in government's backyard so to speak, are likely to be promising in revealing more immediate solutions for and insights into some of the practical organizational and local problems associated with the introduction of information highways and electronic exchange. This can, to some extent, be viewed in parallel with the discussion in section 3: electronic exchange allows not just internal reengineering processes to take place in the public sector, but also new forms of external outsourcing and public-private partnerships. It could be argued that 
the effectiveness and efficiency of the public sector will become, as with infrastructural provisions, a key variable in the competitiveness of countries.

Fourth, many areas dominated by public authorities and public service providers such as education, health, culture, media, social services, immigration, police, libraries and other local services, are typically bound by the geographical limits of the country, province, region or town within which they operate and are administered.

In other words, the wide variety of public information services provides a number of opportunities for information-led growth, whereby such services might both become a cost reduction factor for business and at the same time provide some of the "killer applications" for new consumer-led growth, opening up new market opportunities for private partnerships in the development, distribution and maintenance of new information systems. At the same time, the public sector can help to guarantee reliability, trust, legal security and access and become a model of electronic service provision. The assumption that private parties and the market will by themselves take care of the many new growth opportunities induced by the information highways, is, as we have argued in section 2 , seriously flawed.

\section{CONCLUSIONS}

The focus in most recent documents on e-commerce and the information highways has been on the challenge both for business and policy-makers to bridge the gap between the enormous growth potential offered by the Internet and the limited amount of electronic trade still taking place on the information highways. As argued in section 2 of this paper, this challenge goes far beyond some of the new technical solutions offered for encryption, watermarks, certification authorities, etc., all aimed at organizing new property rules in markets characterized by a lack of excludability. Whether one likes it or not, the development of markets in cyberspace requires a substantial amount of human intervention. To what extent such markets still correspond to the economist's ideal of social optimality must therefore be questioned.

As a result, the scope of relevant policy issues must be broadened. Ecommerce will increasingly raise questions about competition policy with a tendency towards "winner takes all" features in the production of many digital, non-rivalry goods. Questions about open standards, compatibility and interconnectivity will increasingly influence existing competition rules, as will 
issues related to dynamic efficiency; new questions about data protection and consumer privacy will have to be addressed with the emergence of new intermediaries competing for access to customer data; attempts by firms to create artificial rivalry through, for example, continuous upgrading and versioning of goods and services will have to be closely monitored; as will many other directly policy-relevant issues going beyond traditional economic policy concerns.

A discussion of electronic commerce and electronic highways cannot be limited to just issues involving the organization of electronic commercial activities. The information highways provide a vast array of new information and communication access opportunities. The majority of those contribute only indirectly to increased efficiency in economic production and distribution, but mainly involve increased consumer satisfaction, increased well-being and freedom of communication and exchange. It is in this sense that the notion of an emerging Information Society takes on its true value. A society in which ease of communication and access to information and data are not just essential ingredients of economic activity - in the production, distribution and consumption, increasingly, of digital goods and services - but also of leisure, household and other so-called "non-work" activities, of social interaction and of democratic expression. I would argue that easy access to this variety of new "immaterial" goods and services, the largest part of which are not commercially traded, represents to some extent the new wealth of the 21 st century.

Typically, these are goods and services the consumption of which does not lead to the sort of happiness paradox first identified by Tibor Scitovsky in the 1960s that is characteristic of material consumption (Scitovsky, 1976). The consumption of material goods, with its dramatic growth in product innovation and product differentiation (consumers' love of product variety), has become characteristic of the consumption societies of the 1970s and 1980s. As Frank (1997) has argued forcefully, this consumption pattern has also led to a spiral of over-consumption in which individual consumers define happiness ultimately in terms of relative consumption. Happiness is from this perspective closely linked to excludability and rivalry: possessing a more recent car than one's neighbour, wearing a more fashionable dress than one's colleague or possessing a more up-to-date computer than one's boss. By the same token, unhappiness can increase even if one's own consumption remains the same simply because of other people's consumption patterns. Consumption has, in other words, negative externalities. 
By contrast, immaterial network goods and services, I would argue, are typically characterized by positive externalities. Having seen the same movie, read the same book, listened to the same band, opera, or performer - all of these create positive externalities. Consumption of such goods increases social cohesion or, to put it differently, leads to a desire to communicate, to exchange information and to share common impressions. Even if the widespread diffusion of electronic exchange and communication does not in the end create additional value in a narrow economic commercial sense, it could significantly increase well-being and happiness. From this perspective, the Information Society could well represent the trend towards a society less based on material production and consumption, thereby providing a solution to the unsustainable nature, both from an environmental and personal perspective, of material-based output and consumption growth. It is in this sense that the emerging "new economy" should be understood: new global opportunities for information-based, primarily immaterial, production and consumption, some of which might be measured and find their expression in GDP or productivity growth, but most would evaporate in cyberspace, simply increasing the opportunities for visiting, learning, interacting and exchanging ideas and views. 


\section{NOTES}

${ }^{\mathrm{i}}$ Otherwise, how can one explain the fact that security, privacy and payment issues never seemed to raise such major policy questions when Minitel was introduced in France, with its still unchallenged rapid diffusion rate?

ii Even though in some countries the use of mail-order and telephone or television shopping is already quite extensive.

iii The extension of copyrights from 50 to 70 years is a good case in point. The U.S, was instrumental in making the case for this extension, since many early Hollywood movies were in danger of falling into the public domain.

${ }^{\text {iv }}$ Once again, there is no superior invisible hand involved in such a shift. For many centuries, the now developed countries have freely taken ideas, technologies and knowledge from now less developed countries.

"A. line taken, for example, by the recent OECD document on Electronic Commerce prepared for the Ottawa Conference in October 1998 (DSTI/ICCP(98) IS/PART 1-4).

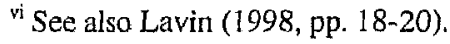




\section{REFERENCES}

A European Initiative in Electronic Commerce, April 15, 1997. www, ispo.cec.be.Ecommerce/initial.html

A Framework for Global Electronic Commerce, July 1, 1997 www. iitf.nist.gov/eleccomm/ecomm.html

Bonn Ministerial Declaration, Industrial Declaration, July 8, 1997

www2.echo.lubonn/final.html

De Long, J. Bradford and A. M. Froomkin, "The Next Economy?" in D. Hurley, B. Kahin, and H. Varian (eds.) Internet Publishing and Beyond: The Economics of Digital and Intellectual Property. Cambridge, MA: MIT Press, 1997.

Electronic Commerce and the Role of the WTO www.wto.org/wto/publicat/newpubl.htm

European Commission, "Building the European Information Society for Us All." Final report of the high-level expert group. Luxembourg: EC, 1997.

Frank, R.H., "The Frame of Reference as a Public Good." Economic Joumal, 107, 1997, 18321847.

Lavin, D., "Why E-Commerce and the Euro Will Pack a Punch." Convergence, IV(3), 1998, 18-20.

OECD, "The Competitive Dynamics of Internet-Based Electronic Commerce." Paris: OECD, 1998.

Scitovsky, T., The Joyless Economy. Oxford: Oxford University Press, 1976.

Towards the Age of the Digital Economy, May 1997

www.wcoomd.org/ecjapan.html

Varian, H. R., "Versioning Information Goods." Paper prepared for Digital Information and Intellectual Property, Harvard University, Jan., 1997, 23-25. 